\title{
Teaching the Climate Crisis: Existential Considerations
}

\author{
Cathryn van Kessel*
}

* University of Alberta, Edmonton, Alberta, Canada.

E-mail: vankesse@ualberta.ca

\section{Article Info}

Received: April 6, 2020

Revised: April 30, 2020

Accepted: May 16, 2020

\section{$10.46303 / \mathrm{jcsr} .02 .01 .8$}

This is an Open Access article distributed under the terms of the CC BY-NC-ND 4.0 International license.

(https://creativecommons.org/licenses/bync-nd/4.0)

\section{How to cite}

Van Kessel, C. (2020). Teaching the climate crisis: Existential considerations. Journal of Curriculum Studies Research, 2(1), 129145. https://doi.org/10.46303/jcsr.02.01.8

\section{ABSTRACT}

It is urgent that educators in social studies and science (among other disciplines) consider the ethical imperative of teaching the climate crisis - the future is at stake. This article considers a barrier to teaching this contentious topic effectively: existential threat. Through the lens of terror management theory, it becomes clear that climate catastrophe is an understandably fraught topic as it can serve as a reminder of death in two ways. As will be explained in this article, simultaneously such discussions can elicit not only mortality salience from considering the necrocene produced by climate catastrophe, but also existential anxiety arising from worldview threat. This threat can occur when Western assumptions are called into question as well as when there is disagreement between those with any worldviews that differ. After summarizing relevant aspects of terror management theory and analyzing the teaching of the climate crisis as an existential affair, specific strategies to help manage this situation (in and out of the classroom) are explored: providing conceptual tools, narrating cascading emotions, carefully using humor to diffuse anxiety, employing language and phrasing that does not overgeneralize divergent groups, and priming ideas of tolerance and even nurturance of difference.

\section{KEYWORDS}

Education; Curriculum studies; Climate change; Science education; Social studies education, Terror management theory. 


\section{INTRODUCTION}

Mass extinctions, ocean acidification, declining air quality, rising tides, more frequent catastrophic storms, and other manifestations of climate catastrophe are direct threats to many entities, including humans. Even the best-case scenario at this point is catastrophic (WallaceWells, 2019). Furthermore, as climate refugees are forced from their land, some of those in power seek to close borders and even kill "what one hates or fears" through the "building of walls and closing of hearts" while others are "offering sanctuary, holding hands with the homeless, feeding the hungry, crossing walls and borders both literal and metaphorical" (Seidel, 2016, p. 63). As educators engage with this issue in the sciences and social studies (among other contexts), it is vital that they attend to the exacerbated emotional terrain that, if left unattended, can lead to the closed hearts that Seidel (2016) mentioned. An aspect of the emotional component of learning about the climate crisis is linked to existential fear-this crisis reminds us $^{1}$ that we, as humans, are vulnerable and can trigger a cascade of reactions related to our defenses against feeling that vulnerability.

A strange proposition for many people is that conscious and unconscious fears of death affect behavior, and yet hundreds of experiments in social psychology reveal this situation to be the case (Pyszczynski, Solomon, \& Greenberg., 2015). Ernest Becker $(1973,1975)$ claimed that humans fear death, and such fear is the root of a lot of defensive behavior; for example, humans cling to what makes them feel more immortal (e.g., cultural worldviews - shared, symbolic conceptions of reality that infuse human existence with a sense of meaning and significance). Terror management theory (TMT) was developed to test those assumptions (Greenberg, Pyszczynski, \& Solomon, 1986). From a TMT perspective, talking about the climate crisis is fraught psychologically because it presents two types of existential threat, a direct reminder of death and an indirect one via worldview threat. As will be further explained later in this article, engagements with the climate crisis remind humans of the inevitability of death; furthermore, people can also experience worldview threat (i.e., when our worldviews' ability to protect against death anxiety is thwarted) when encountering others with opposing beliefs. As such, educators can engage with strategies derived from TMT research to mitigate, or perhaps thwart, barriers to teaching the climate crisis that arise from implicit and explicit fears of death. But first, it is important to consider the thoughtful work already being done in the field of climate crisis teaching.

\footnotetext{
${ }^{1}$ It is intentional that I use the first person here and in a select few other places in this article. Although traditional academic writing tends to avoid this informality, part of the point here is to foster a very real sense of personal implication. Furthermore, I cannot pretend that I am a neutral observer of human behavior; instead, I seek to keep my commitments in perspective in the sense of Donna Haraway's (1988) situated knowledges (see also Lang, 2011).
} 


\section{THE EMOTIONAL TERRAIN OF TEACHING THE CLIMATE CRISIS}

Educators can feel that teaching the climate crisis is imbued with difficulty. One challenge is that the scope of changes in Earth's climate is beyond what a human can glean from personal experience. This problem is further exacerbated by the fact that "personal experience is far more likely to capture a person's attention, and its impact dominates the often far more reliable and diagnostic statistical information" and that some fail to "differentiate very strictly between climate (the statistical expectation) and weather (what we get)" (Weber, 2010, p. 333). Furthermore, familiarity with the risks of climate change "unless accompanied by alarmingly large negative consequences may actually lead to smaller rather than larger perceptions of its riskiness" (Weber, 2010, p. 337). Because of humans' predilection for the status quo, many are reluctant to change their ways. What is familiar to us isn't that bad unless the real consequences are clear, and, yet, humans are psychologically inclined to avoid or defend against such affectively difficult knowledge.

As already explicated by scholars like H. James Garrett (2017), environmental issues are "wrapped in difficult knowledge that makes critical engagement an overwhelming task" (Kissling \& Bell, 2020, p. 6). Difficult knowledge in this context refers to the conceptual frame developed by Deborah Britzman. In 1998, the term represented how teachers and students mourn historical events (war, slavery, genocide, famines, etc.) or social hatred (bigotry, injustice, etc.) that reveal suffering to be caused by human indifference or even disdain for life (Britzman, 1998). More recently, Britzman (2013) has considered how educators might symbolize a variety of challenging emotions in a range of contexts: "the pushes, pulls, and emotional boundaries of learning" (p. 101).

Difficult knowledge is not conceptually difficult, but rather is emotionally charged, and indeed the climate crisis embodies this territory. Garrett (2019) wrote about his experience reading David Wallace-Wells' (2019) book on climate catastrophe:

We are invited to confront a future in which there is no possibility of a continuation of the kind of stability upon which human beings evolved and in which human civilization has operated to this point. Reading the book is a confrontation with existential dread and a sobering encounter with the reality that we are likely past the point of no return. (p. 612) In this way, difficult knowledge recognizes how such encounters can provoke a "sense of crisis, burden, discomfort, or trauma" (Garrett, 2019, p. 612). Given that the climate crisis is a direct reminder of the finite nature of human existence, wrapped in other threatening knowledge, educators might benefit from considering a number of conceptual tools to help them in their teaching. As will be explained below, terror management theory (TMT) is a framework from which educators can develop tools. 


\section{TERROR MANAGEMENT THEORY}

According to TMT, a direct reminder of death affects our actions and opinions (e.g., Greenberg, Porteus, Simon, Pyszczynski, \& Solomon, 1995; McGregor et al., 1998; Solomon, Greenberg, \& Pyszczynski, 2015), whether that be an overt reminder (e.g., writing about death), something more subtle (e.g., being interviewed in front of a funeral parlor), or even a subliminal message (e.g., the word "death" quickly flashed on a computer screen). Humans try to devise ways of "transcending the world of flesh and blood... by devising an 'invisible project' that would assure [our] immortality" (Becker, 1975, p. 63). Such quests for permanence and meaning can take a variety of forms (e.g., romantic relationships, see Mikulincer, Florian, \& Hirschberger, 2003), but the main sources are cultural worldviews (i.e., constructed symbolic conceptions of reality shared by a group) and the self-esteem derived from being a valued member among others who share the same worldview (Schimel, Hayes, \& Sharp, 2018). For over 30 years, there have been more than 500 experiments in divergent countries, revealing various effects of "mortality salience" as well as how "worldview threat" produces the same effects because barriers against impermanence have been thwarted (Pyszczynski et al., 2015).

\section{Mortality Salience}

Experiments testing the mortality salience hypothesis have revealed that reminding people of death temporarily increases their need for protective psychological structures, such as cultural worldviews. Support for this hypothesis has been obtained in divergent geographical and cultural contexts (e.g., Canada, China, Germany, India, Iran, Italy, Israel, Japan, United States). Substantial bodies of evidence have found these effects to be specific to heightened accessibility of death-related thought and different from the effects of thinking of other aversive topics (e.g., uncertainty, social exclusion, intense physical pain, a looming exam). A meta-analysis of empirical studies has shown that the mortality salience hypothesis is a strong one according to the standards of social psychology (Burke, Martens, \& Faucher, 2010).

One of the first studies testing the mortality salience hypothesis was done with municipal court judges in the city of Tucson, Arizona. The assumption was that judges value adherence to laws as a key element of their worldview, and so a reminder of death might lead them to punish transgressors more than they might without a reminder of death. In this study, Rosenblatt and colleagues (1989) had judges review a case brief for a prostitution charge against a sex worker, and then suggest a bond amount for the accused after writing about their own death (versus a controlled condition in which they did not write about their death). Judges who were reminded of their own death reacted more harshly towards the sex workers; they suggested a much higher bond for the accused. Judges who were not reminded of death suggested an average bond of only $\$ 50$ while those who had written about their death set an average bond of $\$ 455$.

Heightened mortality salience can affect people in a variety of ways. In addition to hunkering down in their worldviews, as seen in the Rosenblatt et al. (1989) study, those in a 
state of mortality salience might do such things as protect the symbols that represent their most cherished beliefs (e.g., Greenberg et al., 1995) or behave more recklessly (Taubman-Ben Ari \& Findler, 2010). In the political realm, they might become more drawn to charismatic leaders who defend their beliefs (e.g., Cohen, Solomon, \& Kaplan, 2017). Reminders of death increase prejudice, including religious (Greenberg et al., 1990) as well as national and racial (e.g., Greenberg, Schimel, Martens, Solomon, \& Pyszczynski, 2001), and increases aggression against worldview violators (e.g., Hirschberger et al., 2016; McGregor et al., 1998; Pyszczynski, Abdollahi, Solomon, Greenberg, Cohen, \& Weise, 2006). Reminders of death can produce troubling situations, and when that situation is the climate crisis, such reminders permeate the educational milieu like the very air we breathe.

\section{Worldview Threat}

Worldviews provide literal immortality by explaining how individuals might endure past the death of their physical bodies (e.g., an afterlife, reincarnation, or the recycling of the atoms in the body). Worldviews can also help people achieve symbolic immortality by being part of something larger than themselves. Furthermore, when people achieve what their culture values, they feel that they are significant (i.e., gain self-esteem) (Solomon, Greenberg, \& Pyszczynski, 1991).

Because worldviews are a buffer against existential fear, worldview threat produces death-thought accessibility (i.e., death is more on your mind, conscious or unconsciously), and thus defensive behavior, including prejudicial behavior (e.g., Greenberg et al., 2001; Hayes, Schimel, Arndt, \& Faucher, 2010; Schimel, Hayes, Williams, \& Jahrig, 2007). Worldview threat occurs because an attack on one's worldview (including the self-esteem derived from that worldview) triggers a sense (often unconscious) that our particular worldview might be arbitrary or incorrect, and thus for a moment people can lose their shield against their fears of impermanence and react defensively, at times in hurtful ways.

In a terrifying demonstration of this process, Hayes, Schimel, and Williams (2008) exposed Christian participants to a worldview-threatening article depicting the rise of Islam in Bethlehem (versus a control condition where they read about the aurora borealis). Effects were shown in the experimental condition, as expected (e.g., increased death-thought accessibility and worldview defense), but when half of these participants also read additional information regarding a plane crash that killed more than a hundred Muslims, results showed that the perceived deaths of the experimental group eliminated the threat: their death-thought accessibility and worldview defense remained relatively low. In other words, ordinary humans (i.e., not sociopaths) can be reassured by the elimination of an opposing group if that group has provoked worldview threat.

TMT research highlights how important it is to become aware of disturbing psychological processes, such as those demonstrated by Hayes et al. (2008). The hope, then, is to prevent, 
alter, or otherwise thwart defensive reactions that are potentially harmful. But before examining such implications, a consideration of the existential elements inherent in the specific context of teaching the climate crisis is needed.

\section{THE CLIMATE CRISIS AND EXISTENTIAL THREAT}

Although anxiety and worry often have negative consequences, they can be a precursor to deliberation and helpful action if people can manage to cope with and regulate their emotions "at an individual level and in social processes" (Ojala, 2016, p. 45. See also Ojala, 2013). The overarching goal here, then, is to help educators identify, and thus manage, the existential anxieties their students might experience (and their own), and thus increase the chances of having deliberative conversations instead of angry arguments. Recognizing the interplay of fears of death and how people relate to each other is helpful as humans seek more harmonious ways of being together on this planet.

Drawing from TMT, engaging with the climate crisis in classrooms taps into multiple (and compounding) sources of existential anxiety. Such discussions can elicit both mortality salience and worldview threat, the latter of which can occur when Western culture is called into question as well as when there is disagreement between those with different perspectives. With such a conceptual framework, it is understandable that teaching the climate crisis is so fraught with difficulty.

\section{Mortality Salience and the Climate Crisis}

The climate crisis is terrifying by the very nature of its existence. It demands that humans recognize the real threat of death as a result of environmental devastation and related multispecies extinctions. Our present time can be conceptualized as a necrocene (McBrien, 2016), an era of death and destruction of life itself-through climate-related extinction, natural disasters, and human aggression - as well as the eradication of cultures through forced assimilation:

This becoming extinction is not simply the biological process of species extinction. It is also the extinguishing of cultures and languages, either through force or assimilation; it is the extermination of peoples, either through labor or deliberate murder; it is the extinction of the earth [sic] in the depletion [of] fossil fuels, rare earth minerals, even the chemical element helium; it is ocean acidification and eutrophication, deforestation and desertification, melting ice sheets and rising sea levels; the great Pacific garbage patch and nuclear waste entombment... (pp. 116-117)

Thus, individuals likely experience anxiety about physical and symbolic (e.g., cultural) deaths as well as the potential annihilation of humans as a species. 


\section{Worldview Threat and Western Culture}

Teaching potentially worldview-threatening curriculum can be troubling and troublesome. Boler (2014) aptly identified the angry responses to discussions of issues such as structural oppression as indicators of "someone who is struggling to maintain his or her identity" (p. 27), and, indeed, a TMT analysis of the educational situation of worldview threat supports this interpretation. Students and teachers may experience worldview threat from cultural contexts. Conversations about the climate crisis can be a reminder that the dominant assumptions in places like Canada and the United States about ways of knowing and being in the world are only one of many (e.g., in contrast with worldviews of Indigenous groups). Even more threatening is the idea that the assumptions that dominate in Western societies are perhaps not viable in the long term given the context of climate catastrophe.

As Kissling and Bell (2020) aptly noted, conceptualizations of citizenship and community in social studies (and arguably beyond) desperately need to expand into a "land ethic" (p. 3). Building off the thoughtful work of Aldo Leopold (1949/1966), Kissling and Bell (2020) have called for a recognition of communities that include entities like soil and water. Such a disposition, of course, hearkens to the sort of webbed kinship often articulated as "all my relations," a phrase and sensibility that permeates a variety of Indigenous traditions in North America (King, 1994) and likely elsewhere. Humans were not destined to exploit the planet: "ecocidal logics that now govern our world are not inevitable or 'human nature', but are the result of a series of decisions that have their origins and reverberations in colonization" (Davis \& Todd, 2017, p. 763). This is a vital point because many humans hope for (and seek) a technological fix for climate catastrophe-carbon capture, and so on-but many of these do not address the underlying problems arising from worldviews (e.g., economies based on perpetual growth, land as containing resources for exploitation), and thus such responses are incomplete at best, and at worst would perpetuate the problem in a different way. The maltreatment of the planet has gone hand-in-hand with numerous ethnoracist assumptions and procedures and detrimental effects of capitalism such as monocrop farming, which is why a growing number of scholars and activists are using the term plantationocene (e.g., Ishikawa, 2019). Terms such as plantationocene are helpful, in part, because they do not shy away from root causes of the present predicament. Such contexts are important because some settler educators avoid teaching about their colonial contexts, and this avoidance extends to a lack of acknowledgement regarding how colonial logics have created the climate crisis (Korteweg \& Root, 2016).

A more "ecological worldview" (whether Indigenous or not) runs contrary to the more dominant anthropo/euro/centric worldviews that permeate Western societies (Martusewicz, Edmundson, \& Lupinacci, 2015, p. 11; see also Kissling \& Bell, 2020). Many Western worldviews, housed in Enlightenment thinking, see a particular manifestation of the human - the Western, rational, bourgeois "Man" (Wynter, 2003)-as above other entities. Man is interpreted as separate from other animals as well as other entities on the planet, rather than intertwined and 
interdependent. With such a framing, land becomes a resource for Man's use, and thus the sort of exploitation of land that created the climate crisis to occur. Furthermore, manifestations of this worldview can impede action: "individualism, competition, and consumerist agendas make education about necessary collective action challenging" (Berger, Gerum, \& Moon, 2015, p. 156. See also Levinson, 2012).

Humans' lack of control to stop climate catastrophe destabilizes assumptions that humans are exempt from relationality with the rest of the planet. Some humans fail to see themselves as interconnected beings on this planet, and thus they can suffer from an "environmental neurosis, rooted in deep-seated annihilation anxiety resulting from our denial of our real dependence on nature and based on the illusion of our own autonomy" (Weintrobe, 2012, p. 41; see also Välimäki \& Lehtonen, 2009). Perhaps it is no wonder, then, that "[b]ecause of our profound dependence on nature, climate change shakes the security of the human sense of being at a very basic level" (Lehtonen \& Välimäki, 2012, p. 49). From a TMT perspective, it is important to recognize the worldview threat that may be produced from such discussions that can occur within classrooms.

\section{Worldview Threat and Diverging Perspectives}

In addition to a broad threat to Western worldviews, individual level worldview threat can occur when classmates talking about the climate crisis have different perspectives from each other. Political polarization, for example, can exacerbate an already tense situation within and beyond the classroom. Differing perspectives in relation to perceptions of the climate crisis can produce worldview threat when these diverging viewpoints collide. Differences in worldview entail different perceptions of the risks associated with climate change, such as the extent to which certain industries and technologies are opportunities versus threats (Weber, 2010; see also Dake, 1991; O'Connor, Bord, \& Fisher, 1998, 1999).

Anyone who challenges someone's worldview, directly or indirectly, can heighten the experience of existential terror. Such a threat may be an explicit disagreement, but even the presence of a divergent perspective (without a direct challenge) can have the effect of lowering our worldview's ability to shield against the impermanence of death (for a more robust discussion of worldview threat in educational contexts, please see van Kessel, den Heyer, \& Schimel, 2019).

\section{Defensive Moves}

In response to direct (i.e., mortality salience) or indirect (e.g., worldview threat) existential threat, there are a variety of ways humans can react. Some are subtle, such as a decrease in reading comprehension (Williams, Schimel, Hayes, \& Faucher, 2012) or choosing to sit more closely to those assumed to have shared cultural beliefs and farther away from those who do not (Ochsmann \& Mathy, 1994). In social studies, for example, teachers might avoid the topic of climate crisis because they see it as science (e.g., "That is an area I leave for the Science 
teacher on my academic team" as quoted in Kissling \& Bell, 2020, p. 15), while science teachers might see the topic as more in the domain of social studies due to the links to economic and social policy. Similar avoidance behavior in terms of (a supposed lack of) expertise can be seen in statements such as, "I don't know many details about the reasons for the scientific consensus toward climate change, or the benefits and challenges with regard to fracking, so I am less comfortable planning around these topics" (quoted in Kissling \& Bell, 2020, p. 15). But, teachers are not (and cannot be) experts in everything they teach, and too often teachers might use a lack of qualifications to excuse themselves from worldview threatening information and not from other (non-threatening) content; see, for example, Dwayne Donald's (2009) work on cultural disqualification arguments regarding teaching Indigenous content and methods.

Other defensive compensatory reactions can be more extreme, and TMT theorists have identified four categories (Solomon et al., 2015). The first is derogation-dismissing other views as inferior-and includes insulting the other person/group, such as calling a land defender or an oilfield worker an offensive name (or another sort of ad hominem attack). The second is assimilation - validating your own view by absorbing others-such as virulent attempts to "convert" the other to your view (either as a climate activist or a climate change denier). The third is annihilation-wreaking violence against (or even seeking to eliminate) those with the other worldview, as well as the expression of support for such annihilation (e.g., sexually violent bumper stickers aimed at Greta Thunberg, see Antoneshyn, 2020). The fourth defensive reaction is accommodation - the appropriation of aspects of an opposing worldview to diffuse the perceived threat, such as those who recognize the changes in the global climate but attribute it to "normal" climate cycles instead of a crisis by human means. Given these defensive moves, it is not surprising that educators fear teaching about the climate crisis: "Concerns were noted across the teachers about hostile responses of students, parents, colleagues, administrators, lawmakers, media members, and the general public" (Kissling \& Bell, 2020, p. 16).

\section{Pedagogical Strategies}

Given that the climate crisis can elicit unhelpful defensive moves as a shield from affectively difficult knowledge, educators need to find ways to help students (and themselves) dwell in this discomfort long enough to think through the problems and take appropriate action. A goal of a TMT-informed approach is to encourage a sort of "pedagogy of discomfort" where both educators and students are called upon to analyze critically their "cherished beliefs and assumptions" and provide "a means of creating "space" "instead of rigidly adhering to habit (Boler, 2014, pp. 27-28).

Pedagogical strategies derived from TMT to counteract defensive compensatory reactions include: providing conceptual tools, narrating cascading emotions, carefully using humor to 
diffuse anxiety, employing language and phrasing that does not overgeneralize divergent groups, and priming the idea of tolerance.

\section{Providing Conceptual Tools}

Teaching TMT directly or indirectly helps students to name the emotional terrain educators are asking them to navigate. Although this article engages with TMT specifically, educators could, of course, consider other ways that "locate, acknowledge, and express the range of complex emotions," such as Lisa Korteweg and Emily Root's (2016) "affective education of reconciliation" (p. 185). Regardless of the specific vocabulary used, it is important to acknowledge the existential element. These tools are ideally introduced at the beginning of a course. Then, these concepts can be reiterated whenever the class is going to be engaging with worldview threatening information such as challenges to Western epistemologies, particularly worldviews of local Indigenous peoples and land defenders (e.g., Korteweg \& Root, 2016). Perhaps TMT as a conceptual tool might help teachers and students (as humans) embrace or at least accept their existential situation. As Solomon et al. (2015) noted, humans might manage their existential fear if they "monitor and alter" unhelpful reactions, and thus be "more self-determined in the choices [they] make and the actions [they] take" (p. 225).

\section{Narrating Cascading Emotions}

Educators can model their own struggles with difficult emotions with their students (Garrett, 2017) in addition to having conversations about defensive reactions. This situation can be educative in itself. Teachers can be open with their students, letting them know about their own uncertainties, strong feelings, and frustrations. This sensitivity to students' as well as their own emotions can allow educators to speak directly to what might emerge organically within the context of a lesson. Such 'in the moment' emotional modeling creates space for students to feel, express, name, and work through the difficult emotions that are felt, and important relational connections were drawn that allowed for students to have their feelings named, normalized, and validated. The disruption of worldviews may indeed be a requirement in order to wrestle with the difficult emotions that lay underneath the study of the climate crisis. To have appropriate emotional role modeling done through a skilled teacher creates a safer space for this disruption, and the important resulting consequences, to occur.

\section{Employing Humor Carefully}

Humor is a tactic to deal with existential anxiety (Elgee, 2003). In my own teaching, I often use Internet memes (i.e., popular image macros annotated that have traction on social media) for a cheap laugh to diffuse tension. Much care is needed when employing humor in the context of mortality salience-one must not be glib about someone else's death. Instead, educators could consider how to use humor around associated issues instead of death itself. In other words, I would not make light of species or populations dying, but I might use humor in other situations 
(e.g., about a breakdown in communication or a counterintuitive policy). Another note of caution is also needed: If one includes humor that derogates someone or their worldview, then the prompt that was intended to diffuse anxiety might inadvertently create more via worldview threat.

\section{Refraining from Overgeneralization}

Following the wisdom of Kent den Heyer (2018), I try to avoid generalizations about groups, such as replacing "the" with a qualifier (I use "some but not all"). For example, I would never say, "the workers on the oilfields don't care about the environment." This statement in itself is neither true nor fair. Instead I might say "some but not all folks in the oil industry ignore climate catastrophe, while others are taking it seriously, and many of these folks have different ideas about their relationship to land and the environment." And, conversely, it is not fair to say that "climate activists and land defenders want oilfield workers and their families to starve when no one has work." Instead, "some but not all activists may not care about economic concerns, but many do, and many have plans to protect families from the economic hardships from moving away from oil production." The key is not to essentialize any group. Although perhaps this technique sounds wordy and cumbersome, I have found that students adjust quickly and then the more nuanced phrasing flows naturally.

\section{Priming the Idea of Tolerance}

There is converging evidence that anxiety-induced intolerance can be countered by fostering and rewarding tolerance as an aspect of the cultural worldview. For this to happen, educators need to make tolerance both a value and a highly accessible option (Greenberg, Simon, Pyszczynski, Solomon, \& Chatel, 1992, p. 218; see Vail, Juhl, Arndt, Vess, Routledge, \& Rutjens, 2012, for a review of supporting research). This research explains why some people seem to embrace different worldviews and cultures, even though humans all struggle with the same fears of mortality. If tolerance (or better still, acceptance and nurturance) of difference is made psychologically accessible, then people might be able to dialogue about this tough issue. Canada, the United States, and many other countries are places that claim to be democracies, and so of course there is going to be disagreement on issues because that is inherent in a democratic system with multiple voices. Perhaps educators can manage some of the deep existential roots of defensive and offensive behavior so that genuine conversations can happen. Members of democratic societies desperately need thoughtful (and not defensive) dialogue to decide how to tackle the very real problem of climate catastrophe. 


\section{A CONCLUDING THOUGHT}

It is urgent for educators to manage the deep existential roots of the barriers to education and activism about the climate crisis, both their own and those of their students. As Kissling and Bell (2020) asserted:

As we stare down worsening storms, droughts, and wildfires, the field of social studies education has an opportunity for change. First, the field must explicitly acknowledge the ecological crisis, calling out the political-but-not-scientific controversy that often surrounds it, and how the roots of the crisis are cultural and created by human living, particularly in highly-industrialized countries like the United States. (p. 19)

Indeed, this urgent area of education requires "all hands on deck," so to speak. Educators from a variety of locations, research approaches, and identities need to examine how they might shift discourse on the climate crisis within and beyond the classroom. Now is not the time for a single "best practice." Now is the time for educators to consider a variety of conceptual and practical tools, and then try them out with each group of humans they encounter, whether that be students, parents, administration, or politicians. This article provides one way (of many) to consider the barriers to meaningful engagements about the urgent problem of climate catastrophe.

\section{REFERENCES}

Antoneshyn, A. (2020, February 27). Disturbing 'Greta' decal bearing Alta. oilfield company logo drawing criticism. CTV News. Retrieved from https://edmonton.ctvnews.ca/disturbing-greta-decal-bearing-alta-oilfield-companylogo-drawing-criticism-1.4830344

Becker, E. (1973). The denial of death. New York, NY: Free Press.

Becker, E. (1975). Escape from evil. New York, NY: Free Press.

Berger, P., Gerum, N., \& Moon, M. (2015). “Roll up your sleeves and get at it!” Climate change education in teacher education. Canadian Journal of Environmental Education, 20,154172. Retrieved from https://cjee.lakeheadu.ca/article/view/1370

Boler, M. (2014). Teaching for hope: The ethics of shattering worldviews. In V. Bozalek \& B. Leibowitz (Eds.), Discerning critical hope in educational practices (pp. 26-39). New York, NY: Routledge.

Britzman, D. P. (1998). Lost subjects, contested objects: Toward a psychoanalytic inquiry of learning. Albany, NY: State University of New York Press.

Britzman, D. P. (2013). Between psychoanalysis and pedagogy: Scenes of rapprochement and alienation. Curriculum Inquiry, 43, 95-117. https://doi.org/10.1111/curi.12007 
Burke, B. L., Martens, A., \& Faucher, E. H. (2010). Two decades of terror management theory: A meta-analysis of mortality salience research. Personality and Social Psychology Review, 14, 155-195. https://doi.org/10.1177/1088868309352321

Cohen, F., Solomon, S., \& Kaplin, D. (2017). You're hired! Mortality salience increases Americans' support for Donald Trump. Analyses of Social Issues and Public Policy, 17, 339-357. https://doi.org/10.1111/asap.12143

Dake, K. (1991). Orienting dispositions in the perception of risk: An analysis of contemporary worldviews and cultural biases. Journal of Cross-Cultural Psychology, 22, 61-82. https://doi.org/10.1177/0022022191221006

Davis, H., \& Todd, Z. (2017). On the importance of a date, or decolonizing the Anthropocene. ACME: An International E-Journal for Critical Geographies, 16(4), 761-780.

https://www.acme-journal.org/index.php/acme/article/view/1539

den Heyer, K. (2018). Next acts: Educational impasse, events and a one-legged magpie.

Edmonton, Canada: The Alberta Teachers' Association. Retrieved from https://www.teachers.ab.ca/SiteCollectionDocuments/ATA/Publications/Research/CO OR-101-16\%20Next\%20Acts\%20Monograph 2018-08.pdf

Donald, D. T. (2009). The curricular problem of Indigenous: Colonial frontier logics, teacher resistances, and the acknowledgement of ethical space. In J. Nahachewsky \& I. Johnston (Eds.), Beyond 'presentism': Reimagining the historical, personal, and social places of curriculum. Rotterdam, Netherlands: Sense.

https://doi.org/10.1163/9789460910012 004

Elgee, N. J. (2003). Laughing at death. The Psychoanalytic Review, 90, 1-23.

https://www.doi.org/10.1521/prev.90.4.475.23917

Garrett, H. J. (2017). Learning to be in the world with others: Difficult knowledge and social studies education. New York, NY: Peter Lang. https://doi.org/10.3726/978-1-43313966-6

Garrett, H. J. (2019). Learning to tolerate the devastating realities of climate crisis. Theory \& Research in Social Education, 47, 609-614. https://doi.org/10.1080/00933104.2019.1656989

Greenberg, J., Porteus, J., Simon, L., Pyszczynski, T., and Solomon, S. (1995). Evidence of a terror management function of cultural icons: The effects of mortality salience on the inappropriate use of cherished cultural symbols. Personality and Social Psychology Bulletin, 21, 1221-1228. https://doi.org/10.1177/01461672952111010

Greenberg, J., Pyszczynski, T., \& Solomon, S. (1986). The causes and consequences of a need for self-esteem: A terror management theory. In R. F. Baumeister (Ed.), Public self and private self (pp. 189-212). New York, NY: Springer-Verlag.

https://www.doi.org/10.1007/978-1-4613-9564-5 10 
Greenberg, J., Pyszczynski, T., Solomon, S., Rosenblatt, A., Veeder, M., Kirkland, S., \& Lyon, D. (1990). Evidence for terror management theory II: The effects of mortality salience on reaction to those who threaten or bolster the cultural worldview. Journal of Personality and Social Psychology, 58, 308-318. https://www.doi.org/10.1037/0022-3514.58.2.308

Greenberg, J., Schimel, J., Martens, A., Solomon, S., \& Pyszczynski, T. (2001). Sympathy for the devil: Evidence that reminding whites of their mortality projects promotes more favorable reactions to white racists. Motivation and Emotion, 25, 113-133.

https://www.doi.org/10.1023/A:1010613909207

Greenberg, J., Simon, L., Pyszczynski, T., Solomon, S., \& Chatel, D. (1992). Terror management theory and tolerance: Does mortality salience always intensify negative reactions to others who threaten one's worldview? Journal of Personality and Social Psychology, 63, 212-220. https://doi.org/10.1037//0022-3514.63.2.212

Haraway, D. (1988). Situated knowledges: The science question in feminism and the privilege of partial perspective. Feminist Studies, 14, 575-599.

http://www.jstor.org/stable/3178066

Hayes, J., Schimel, J., Arndt, J., \& Faucher, E. H. (2010). A theoretical and empirical review of the death-thought accessibility concept in terror management research. Psychological Bulletin, 136, 699-739. https://www.doi.org/10.1037/a0020524

Hayes, J., Schimel, J., \& Williams, T. J. (2008). Fighting death with death: The buffering effects of learning that worldview violators have died. Psychological Science, 19, 501-507. https://www.doi.org/10.1111/j.1467-9280.2008.02115.x

Hirschberger, G., Pyszczynski, T., Ein-Dor, T., Shani Sherman, T., Kadah, E., Kesebir, P., \& Park, Y. C. (2016). Fear of death amplifies retributive justice motivations and encourages political violence. Peace and Conflict: Journal of Peace Psychology, 22, 67-74. https://doi.org/10.1037/pac0000129

Ishikawa, N. (2019). Into a new epoch: Capitalist nature in the plantationocene. In N. Ishikawa \& R. Soda (Eds). Anthropogenic tropical forests: Advances in Asian humanenvironmental research (pp. 589-594). Springer. https://doi.org/10.1007/978-981-137513-2 28

King, T. (Ed.). (1994). All my relations. Toronto, Canada: McClelland and Stewart.

Kissling, M. T., \& Bell, J. T. (2020). Teaching social studies amid ecological crisis. Theory \& Research in Social Education, 48, 1-31.

https://doi.org/10.1080/00933104.2019.1673267

Korteweg, L., \& Root, E. (2016). Witnessing kitchenuhmaykoosib inninuwug's strength and struggle: The affective education of reconciliation in environmental education. Canadian Journal of Environmental Education, 21, 178-197. 
Lang, J. C. (2011). Epistemologies of situated knowledges: "Troubling" knowledge in philosophy of education. Educational Theory, 61, 75-96.

https://doi.org/10.1111/i.1741-5446.2011.00392.x

Lehtonen, J., \& Välimäki, J. (2012). Discussion: The difficult problem of anxiety in thinking about climate change. In S. Weintrobe (Ed.), Engaging with climate change:

Psychoanalytic and Interdisciplinary Perspectives (pp. 48-55). New York, NY: Routledge. https://doi.org/10.4324/9780203094402

Leopold, A. (1966). A Sand County almanac. New York, NY: Oxford University Press.

Levinson, R. (2012). A perspective on knowing about global warming and a critical comment about schools and curriculum in relation to socio-scientific issues. Cultural Studies of Science Education, 7, 693-701. https://doi.org/10.1007/s11422-012-9418-y

Martusewicz, R. A., Edmundson, J., \& Lupinacci, J. (2015). EcoJustice education: Towards diverse, democratic, and sustainable communities (2nd ed.). New York, NY: Routledge. https://www.doi.org/10.4324/9781315779492

McBrien, J. (2016) Accumulating extinction: Planetary catastrophism in the necrocene. In J. W. Moore (Ed.), Anthropocene or Capitalocene? Nature, history, and the crisis of capitalism (pp. 116-137). Oakland, CA: PM Press.

McGregor, H., Lieberman, J. D., Solomon, S., Greenberg, J., Arndt, J., Simon, L., \& Pyszczynski, T. (1998). Terror management and aggression: Evidence that mortality salience motivates aggression against worldview threatening others. Journal of Personality and Social Psychology, 74, 590-605. https://www.doi.org/10.1037/0022-3514.74.3.590

Mikulincer, M., Florian, V., \& Hirschberger, G. (2003). The existential function of close relationships: Introducing death into the science of love. Personality and Social Psychology Review, 7, 20-40. https://www.doi.org/10.1207/S15327957PSPR0701 2

O'Connor, R. E., Bord, R. J., \& Fisher, A. (1998). The curious impact of knowledge about climate change on risk perceptions and willingness to sacrifice. Risk Decision and Policy, 3, 145155.

O'Connor, R.E., Bord, R. J., \& Fisher, A. (1999). Risk perceptions, general environmental beliefs, and willingness to address climate change. Risk Analysis, 19, 461-471.

https://www.doi.org/10.1111/j.1539-6924.1999.tb00421.x

Ochsmann, R., \& Mathy, M. (1994). Depreciating of and distancing from foreigners: Effects of mortality salience. Unpublished manuscript, Universität Mainz, Germany.

Ojala, M. (2013). Emotional awareness: On the importance of including emotional aspects in education for sustainable development (EDS). Journal of Education for Sustainable Development, 7, 162-182. https://www.doi.org/10.1177/0973408214526488

Ojala, M. (2016). Facing anxiety in climate change education: From therapeutic practice to hopeful transgressive learning. Canadian Journal of Environmental Education, 21, 41- 
56. Retrieved from http://oru.diva-

portal.org/smash/record.jsf?pid=diva2\%3A1039954\&dswid=4420

Pyszczynski, T., Abdollahi, A., Solomon, S., Greenberg, J., Cohen, F., \& Weise, D. (2006).

Mortality salience, martyrdom, and military might: The Great Satan versus the Axis of

Evil. Personality and Social Psychology Bulletin, 32, 525-537.

https://www.doi.org/10.1177/0146167205282157

Pyszczynski, T., Solomon, S., Greenberg, J. (2015). Thirty years of terror management theory:

From genesis to revelation. Advances in Experimental Social Psychology, 52, 1-70.

https://www.doi.org/10.1016/bs.aesp.2015.03.001

Rosenblatt, A., Greenberg, J., Solomon, S., Pyszczynski, T., \& Lyon, D. (1989). Evidence for terror management theory: I. The effects of mortality salience on reactions to those who violate or uphold cultural values. Journal of Personality and Social Psychology, 57, 681-690. https://www.doi.org/10.1037/0022-3514.57.4.681

Schimel, J., Hayes, J., Sharp, M. (2018). A consideration of three critical hypotheses. In C. Routledge \& M. Vess (Eds.) The handbook of terror management theory (pp 1-25). London, England: Academic Press. https://www.doi.org/10.1016/c2016-0-02231-3 Schimel, J., Hayes, J., Williams, T., \& Jahrig, J. (2007). Is death really the worm at the core? Converging evidence that worldview threat increases death-thought accessibility. Journal of Personality and Social Psychology, 92(5), 789-

803. https://www.doi.org/10.1037/0022-3514.92.5.789

Seidel, J. (2016). Curriculum lessons from ecopsychology. In j. jagodzinski (Ed.), The precarious future of education (53-69). New York, NY: Palgrave Macmillan.

https://www.doi.org/10.1057/978-1-137-48691-2

Solomon, S., Greenberg, J., \& Pyszczynski, T. (1991). A terror management theory of social behavior: The psychological functions of self-esteem and cultural worldviews. Advances in Experimental Social Psychology, 24, 93-159. https://doi.org/10.1016/S00652601(08)60328-7

Solomon, S., Greenberg, J., \& Pyszczynski, T. (2015). The worm at the core: On the role of death in life. New York, NY: Random House.

Taubman-Ben Ari., O. \& Findler, L. (2010). Reckless driving and gender: An examination of a terror management theory explanation. Death Studies, 27, 603-618. https://doi.org/10.1080/07481180302898

Vail, K. E., Juhl, J., Arndt, J., Vess, M., Routledge, C., \& Rutjens, B. (2012). When death is good for life: Considering the positive trajectories of terror management. Personality and Social Psychology Review, 16, 303-329. https://doi.org/10.1177/1088868312440046

Välimäki, J., \& Lehtonen, J. (2009). Ilmastonmuutiksen torjuntaan tarvitaan johtajuutta [Leadership is required for counteracting climate change]. Kanava, 37, 341-344. 
van Kessel, C., den Heyer, K., \& Schimel, J. (2019). Terror management theory and the educational situation. Journal of Curriculum Studies. Advanced online publication. https://doi.org/10.1080/00220272.2019.1659416

Wallace-Wells, D. (2019). The uninhabitable Earth: Life after warming. New York NY: Tim Duggan.

Weber, E. U. (2010). What shapes perceptions of climate change? Wiley Interdisciplinary Reviews: Climate Change, 1(3), 332-342. https://www.doi.org/10.1002/wcc.41

Weintrobe, S. (2012). The difficult problem of anxiety in thinking about climate change. In S. Weintrobe (Ed.), Engaging with climate change: Psychoanalytic and Interdisciplinary Perspectives (pp. 33-47). New York, NY: Routledge. https://www.doi.org/10.4324/9780203094402

Williams, T. J., Schimel, J., Hayes, J., \& Faucher, E. H. (2012). The effects of existential threat on reading comprehension of worldview affirming and disconfirming information.

European Journal of Social Psychology, 42, 602-616. https://www.doi.org/10.1002/ejsp.1849

Wynter, S. (2003). Unsettling the coloniality of being/power/truth/freedom: Toward the human, after Man, its overrepresentation-An argument. The New Centennial Review, 3, 257-337. http://www.jstor.org/stable/41949874 